\title{
Risk and Environmental Factors Associated with the Presence of Canine Parvovirus Type 2 in Diarrheic Dogs from Thessaly, Central Greece
}

\author{
Maria Kantere ${ }^{1}$, Labrini V. Athanasiou ${ }^{1}$ (D), Alexios Giannakopoulos ${ }^{1}$, Vassilis Skampardonis ${ }^{1}$, Marina Sofia ${ }^{1}$, \\ George Valiakos ${ }^{1}$ D , Zoi Athanasakopoulou ${ }^{1}$, Antonia Touloudi ${ }^{1}$, Dimitris C. Chatzopoulos ${ }^{1,2}$, Vassiliki Spyrou ${ }^{3}$ \\ and Charalambos Billinis ${ }^{1,2, *(D)}$
}

Citation: Kantere, M.; Athanasiou, L.V.; Giannakopoulos, A.;

Skampardonis, V.; Sofia, M.; Valiakos,

G.; Athanasakopoulou, Z.; Touloudi,

A.; Chatzopoulos, D.C.; Spyrou, V.;

et al. Risk and Environmental Factors

Associated with the Presence of

Canine Parvovirus Type 2 in

Diarrheic Dogs from Thessaly,

Central Greece. Pathogens 2021, 10,

590. https://doi.org/10.3390/

pathogens 10050590

Academic Editors: Eva Spada and

Daniela Proverbio

Received: 20 April 2021

Accepted: 9 May 2021

Published: 12 May 2021

Publisher's Note: MDPI stays neutral with regard to jurisdictional claims in published maps and institutional affiliations.

Copyright: (C) 2021 by the authors Licensee MDPI, Basel, Switzerland. This article is an open access article distributed under the terms and conditions of the Creative Commons Attribution (CC BY) license (https:// creativecommons.org/licenses/by/ $4.0 /)$.
1 Faculty of Veterinary Science, University of Thessaly, 43100 Karditsa, Greece; mkantere@uth.gr (M.K.); lathan@uth.gr (L.V.A.); algiannak@uth.gr (A.G.); bskamp@uth.gr (V.S.); msofia@uth.gr (M.S.); georgevaliakos@uth.gr (G.V.); zathanas@uth.gr (Z.A.); atoul@uth.gr (A.T.); dchatzopoulos@uth.gr (D.C.C.)

2 Faculty of Public and Integrated Health, University of Thessaly, 43100 Karditsa, Greece

3 Faculty of Animal Science, University of Thessaly, 41110 Larissa, Greece; vasilikispyrou@uth.gr

* Correspondence: billinis@uth.gr

\begin{abstract}
Canine parvovirus type 2 (CPV-2) primarily infects dogs, which are the main host reservoir, causing severe gastrointestinal disease associated with immunosuppression. The present study was conducted in Thessaly, Greece and aimed to identify risk and environmental factors associated with CPV-2 infection in diarrheic dogs. Fecal samples were collected from 116 dogs presenting diarrhea and were tested by polymerase chain reaction (PCR) for the presence of CPV-2 DNA. Supplementary data regarding clinical symptoms, individual features, management factors and medical history were also gathered for each animal during clinical evaluation. Sixty-eight diarrheic dogs were found to be positive for the virus DNA in their feces. Statistical analysis revealed that CPV-2 DNA was less likely to be detected in senior dogs, while working dogs, namely hounds and shepherds, had higher odds to be positive for the virus. Livestock density and land uses, specifically the categories of discontinuous urban fabric and of human population density, were identified as significant environmental parameters associated with CPV-2 infection by using Geographical Information System (GIS) together with the Ecological Niche Model (ENM). This is the first description of the environmental variables associated with the presence of CPV-2 DNA in dogs' feces in Greece.
\end{abstract}

Keywords: Canine parvovirus type 2 (CPV-2); diarrheic dogs; polymerase chain reaction; risk factors; environmental parameters; spatial analysis

\section{Introduction}

Canine parvovirus type 2 (CPV-2) of the Parvoviridae family is an ubiquitous virus with worldwide distribution $[1,2]$ and is considered as a major viral pathogen of dogs. CPV-2 is a small, non-enveloped single-stranded DNA virus with three antigenic variants, CPV-2a, CPV-2b and CPV-2c [2]. The virus replicates in rapidly dividing cells of lymphoid tissues, intestinal crypt epithelial cells, precursor cells in the bone marrow and myocardiocytes in puppies under the age of one month [3].

CPV-2 causes acute enteritis with high mortality rates in young animals and also affects adults [4]. Clinical symptoms include anorexia, depression, vomiting, profuse hemorrhagic diarrhea, abdominal pain, dehydration and pyrexia, while the more severe hematological alteration is leukopenia as a result of destruction of hematopoietic progenitor cells in the bone marrow [5]. Recent reports, based on laboratory testing of feces from dogs with clinical signs, have reported prevalence of CPV-2 infection that varied among various countries from $23.6 \%$ in Netherlands, $27.7 \%$ in Spain, $53.8 \%$ in Italy, $61.5 \%$ in France, $71.4 \%$ in Germany, $70.2 \%$ in Colombia, $75 \%$ in Nigeria, $99.24 \%$ in regions of China, $91.67 \%$ in Bulgaria and $92.98 \%$ in Albania [1,6-11]. The virus is usually transmitted via fecal-oral 
route following contact with contaminated feces, soil or fomites, but also via predation, scavenging of carcasses, or oronasally [12]. It is shed at high titers in feces of infected animals within 4 to 5 days from exposure and for up to 10 days after recovery [13] and can persist in the environment for a time period more than a year [14], facilitating exposure of susceptible animals to infected fomites.

The most frequently reported risk factor for developing a CPV-2-caused disease is inadequate protective immunity [15]. Several factors have been reported to be associated with virus infection, including age (young < 12 months) [16], breed (purebred) [17], clinical signs as lethargy and depression [18], seasonality [16], geographical region [16], freeranging behavior [19], inadequate veterinary health care [19], rural area of residence [16], overcrowding unsanitary environment [3,20], insufficient anthelminthic prophylaxis [21], social and financial disadvantage of owner [22,23] and lower rates of rainfall [23,24]. Moreover, a previous study in Greece reported on risk factors related to prognosis and treatment outcome [17]. In particular, prolonged duration of hospitalization was associated with dogs' depression, vomiting, lymphopenia or hypoalbuminemia upon admission, while the syndrome of Systemic Inflammatory Response (SIRS) was correlated with poor prognosis [17].

Spatial analysis has been implemented to compare either CPV-2 prevalence in dogs between rural and urban regions by using serological methods [16,25] or exposure of dogs to the pathogen in regions where dog-wildlife interaction occurred [19]. A recent study from Australia reported large numbers of CPV cases in dogs of rural and remote areas $[23,26]$ by using spatial analysis combined with molecular diagnosis. Currently in Greece, there is a lack of information on environmental parameters associated with the virus presence.

The present study aimed to assess the importance of CPV-2 as a causative agent of diarrhea in dogs, to determine potential risk factors and environmental parameters associated with the virus presence and to identify possible high-risk areas by using spatial analysis for virus surveillance and control for the first time in Greece.

\section{Results}

\subsection{CPV-2 Confirmed Infections in Diarrheic Dogs}

A total of 116 dogs with diarrhea, originating from the Region of Thessaly in Greece, were tested by PCR for the presence of CPV-2 DNA in their feces. Virus DNA was amplified in $68(68 / 116,58.1 \%)$, while it was not detected in 48 dogs $(48 / 116,41.4 \%)$. Positive dogs were reported in the Regional Units of Karditsa $(n=19)$, Larissa $(n=15)$, Magnesia $(n=23)$ and Trikala $(n=11)$. The geographical distribution of the confirmed CPV-2 infections is depicted in Figure 1.

Among the 116 diarrheic dogs, CPV2-DNA was detected in 40 males (40/116, 34.5\%) and 28 females $(28 / 116,24.1 \%)$. Furthermore, dogs were classified into three age groups and the virus presence was reported in 33 young ( $<1$ years old, 33/116, 28.4\%), 31 adults ( $\geq 1$ and $<9$ years old, $31 / 116,26.7 \%$ ) and 4 seniors ( $\geq 9$ years old, $4 / 116,3.4 \%$ ). Regarding their utility, CPV-2 DNA was identified in 16 stray animals (16/116, 13.8\%), 35 companion $(35 / 116,30.2 \%)$ and 17 working dogs (17/116, 14.7\%), namely, shepherd dogs and hounds. In respect to living environment, virus presence was confirmed in 6 dogs living indoors (6/116, 5.2\%), 45 living outdoors $(45 / 116,38.8 \%)$ and 17 living both indoors and outdoors $(17 / 116,14.7 \%)$. As for close interaction with other animals, 20 positive dogs were in contact with other dogs $(20 / 116,17.2 \%), 19$ with cats $(19 / 116,16.4 \%)$ and 29 with other animal species $(29 / 116,25 \%)$. At least one more clinical finding compatible with parvoviral enteritis was reported in 63 cases. In particular, 50 dogs exhibited hemorrhagic diarrhea (50/116, 43.1\%), 20 vomiting (20/116, 17.2\%), 18 fever $(18 / 116,15.5 \%), 12$ anorexia (12/116, $10.3 \%), 7$ hypothermia $(7 / 116,6 \%)$ and 4 abnormal findings in abdominal palpation $(4 / 116$, $3.4 \%$ ). The results are summarized in Table 1. 


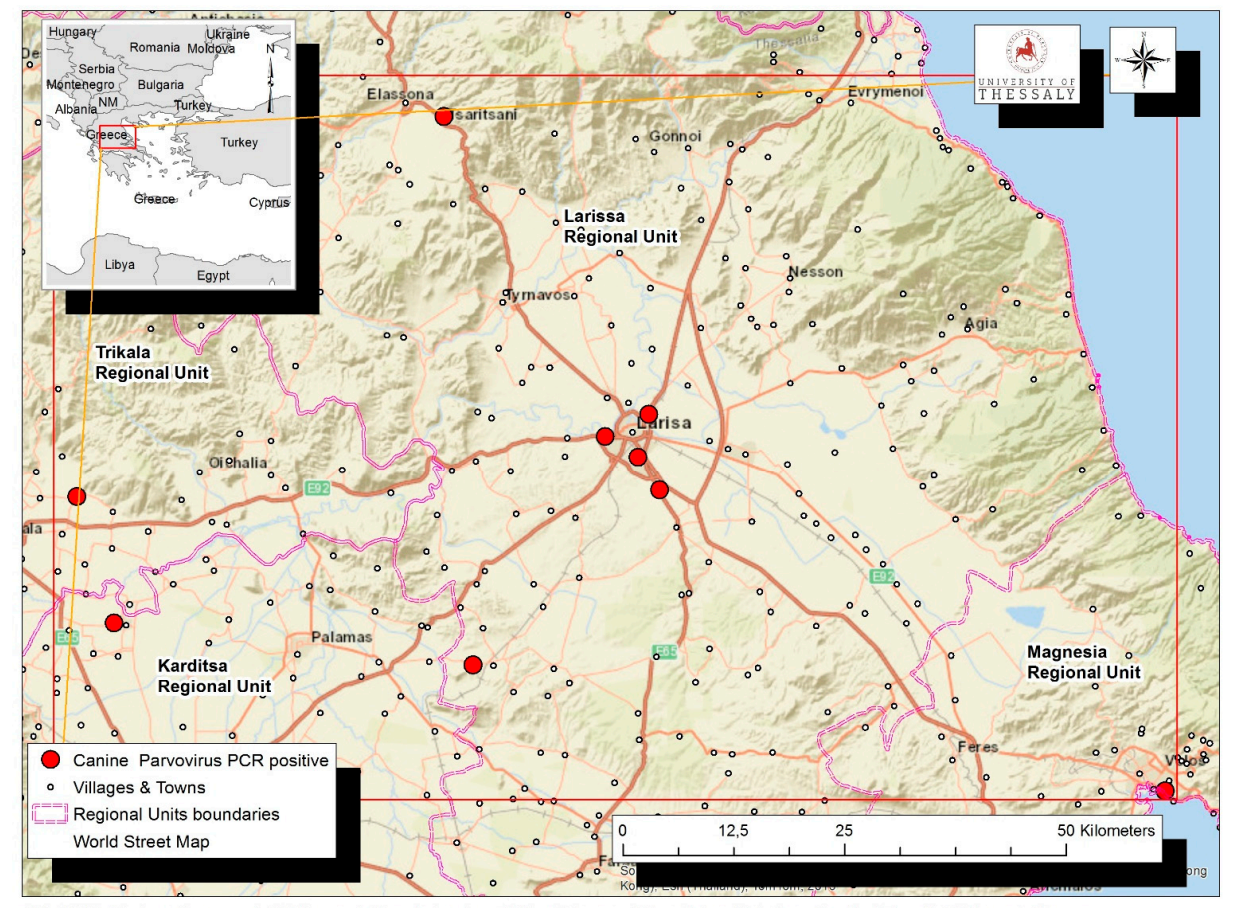

GIS:Wild life Ecology, Zoonoses \& GIS Research Team Laboratory of Microbiology and Parasitology, Veterinary Faculty University Of Thessaly Greece

Figure 1. Map of Thessaly Region in Greek mainland depicting with red dots the geographical distribution of the confirmed 68 CPV-2 infections in the Regional Units of Karditsa, Larissa, Magnesia and Trikala.

Table 1. CPV-2 positive and negative dogs in association with ten factors and their respective categories.

\begin{tabular}{|c|c|c|c|c|}
\hline \multirow{2}{*}{ Factors } & \multirow{2}{*}{ Categories } & \multicolumn{3}{|c|}{ Number of Dogs } \\
\hline & & Total & CPV-2 Positive & CPV-2 Negative \\
\hline \multirow{2}{*}{ Gender } & Male & 66 & 40 & 26 \\
\hline & Female & 50 & 28 & 22 \\
\hline \multirow{3}{*}{ Age * } & $<1$ years old & 48 & 33 & 15 \\
\hline & $\geq 1$ and $<9$ years old & 54 & 31 & 23 \\
\hline & $\geq 9$ years old & 14 & 4 & 10 \\
\hline \multirow{3}{*}{ Utility * } & Pet & 67 & 35 & 32 \\
\hline & Working dog & 18 & 17 & 1 \\
\hline & Stray dog & 31 & 16 & 15 \\
\hline \multirow{3}{*}{ Living environment } & Indoors & 13 & 6 & 7 \\
\hline & Outdoors & 73 & 45 & 28 \\
\hline & Both & 30 & 17 & 13 \\
\hline \multirow{3}{*}{ Contact } & Dog & 31 & 20 & 11 \\
\hline & Cat & 33 & 19 & 14 \\
\hline & Other animal species & 52 & 29 & 23 \\
\hline \multirow{2}{*}{ Abdominal palpation } & Normal findings & 105 & 64 & 41 \\
\hline & Abnormal findings & 11 & 4 & 7 \\
\hline \multirow{2}{*}{ Anorexia } & Presence & 22 & 12 & 10 \\
\hline & Absence & 94 & 56 & 38 \\
\hline \multirow{2}{*}{ Hemorrhagic diarrhea } & Presence & 80 & 50 & 30 \\
\hline & Absence & 36 & 18 & 18 \\
\hline \multirow{3}{*}{ Body Temperature } & $\begin{array}{l}\text { Within reference } \\
\text { interval }\end{array}$ & 78 & 43 & 35 \\
\hline & Fever & 27 & 18 & 9 \\
\hline & Hypothermia & 11 & 7 & 4 \\
\hline \multirow{2}{*}{ Vomiting } & Presence & 35 & 20 & 15 \\
\hline & Absence & 81 & 48 & 33 \\
\hline
\end{tabular}

* Statistically significant factors are shown with background gray color. 
Unfortunately, information about vaccination, deworming and diet were gathered only for the categories of pets and working dogs $(n=85)$, but not for stray animals due to their unknown clinical history. Specifically, CPV-2 DNA was detected in the feces of 32 vaccinated and of 20 unvaccinated dogs, as well as in 33 dogs that received deworming therapy and in 20 that did not. In view of diet, positive dogs for the virus consumed dry food $(n=13)$, raw food $(n=5)$, homemade food $(n=8)$ or a combination of the abovementioned categories $(n=26)$.

\subsection{Statistical Analysis}

After the screening process, three parameters, namely, age, utility and presence of diarrhea, were eligible for inclusion in the full model. After model building, only two variables were significant, age and utility, and retained in the final model. Their interaction was not significant $(p=0.453)$. Hosmer-Lemeshow $(p=0.28)$ test suggested an overall adequate fit of the model to the data. Senior dogs were 4.18 ( $p=0.034,95 \%$ CI: 1.11-15.87) times less likely to be positive for detection of CPV-2 DNA in their feces, compared to young dogs. The odds of CPV-2 DNA detection in feces did not significantly differ between young and adult dogs $(p=0.246)$ and between adult and old dogs $(p=0.166)$. A significant association between the utility of the dog and CPV-2 DNA presence in feces was detected. Specifically, working dogs (shepherd dogs and hounds) were 13.18 ( $p=0.015$, 95\% CI: 1.64-106.00) and 14.12 ( $p=0.016,95 \%$ CI: $1.62-122.00)$ times more likely to be positive for the presence of CPV-2 DNA in their feces compared to pet and stray dogs, respectively. The odds of CPV-2 DNA detection in feces did not differ between pet and stray dogs $(p=0.88)$.

\subsection{Predictive Ecological Niche Modeling (ENM) of Canine CPV-2 Cases}

All 68 diarrheic dogs in which CPV-2 DNA was detected in their feces, were used as occurrence points for the Ecological Niche Modeling (ENM) procedure and the appropriate ecological niches for the virus presence were predicted by MaxEnt software version 3.3.3 [27]. Nine of the 34 environmental parameters included in the analysis were found to contribute to the model, as presented in Table 2. Model fitness was evaluated by a receiver operating characteristic (ROC) curve that gave a value of 0.983 for the mean area under the curve (AUC) and exceeded AUC $=0.5$ of random prediction (Figure 2). Jackknife test was used to reduce the number of environmental variables to the ones with a substantial influence on the model, as it is demonstrated in Figure 3.

Table 2. Contributions of the environmental variables to the Maxent model including percent contribution and permutation importance.

\begin{tabular}{cccc}
\hline Environmental Variable & Code & Percent Contribution & Permutation Importance \\
\hline Livestock density & goatsden & 50.9 & 76.3 \\
\hline Human population density & popden & 27.6 & 1.5 \\
\hline Land uses & landcorine & 12.8 & 3.7 \\
\hline June NDVI & junendvi & 2.6 & 3.8 \\
\hline Distance from small ruminant farms & farmsdis & 1.8 & 0 \\
\hline Altitude & dem & 1.3 & 0.3 \\
\hline Annual mean temperature & clima1 & 1.3 & 11 \\
\hline Total annual precipitation & clima12 & 0.8 & 2.9 \\
\hline Distance from water collections & waterdis & 0.2 \\
\hline
\end{tabular}

\footnotetext{
${ }^{1}$ NDVI: normalized difference vegetation index.
} 


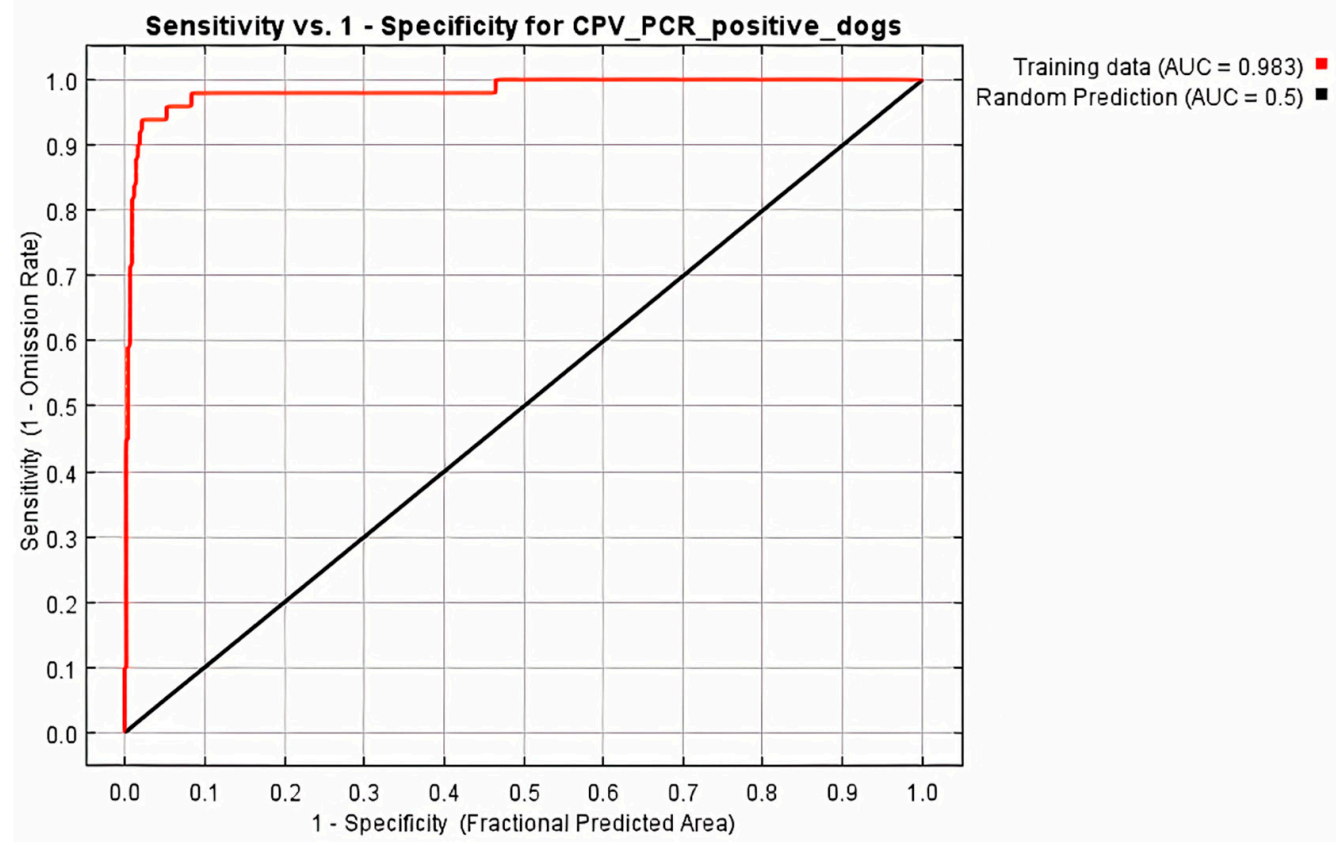

Figure 2. Receiver operating characteristic (ROC) curve of Maxent model for CPV-2 DNA positive dogs. The area under the curve (AUC) had value of 0.983 and exceeded that of random prediction (AUC $=0.5$ ).

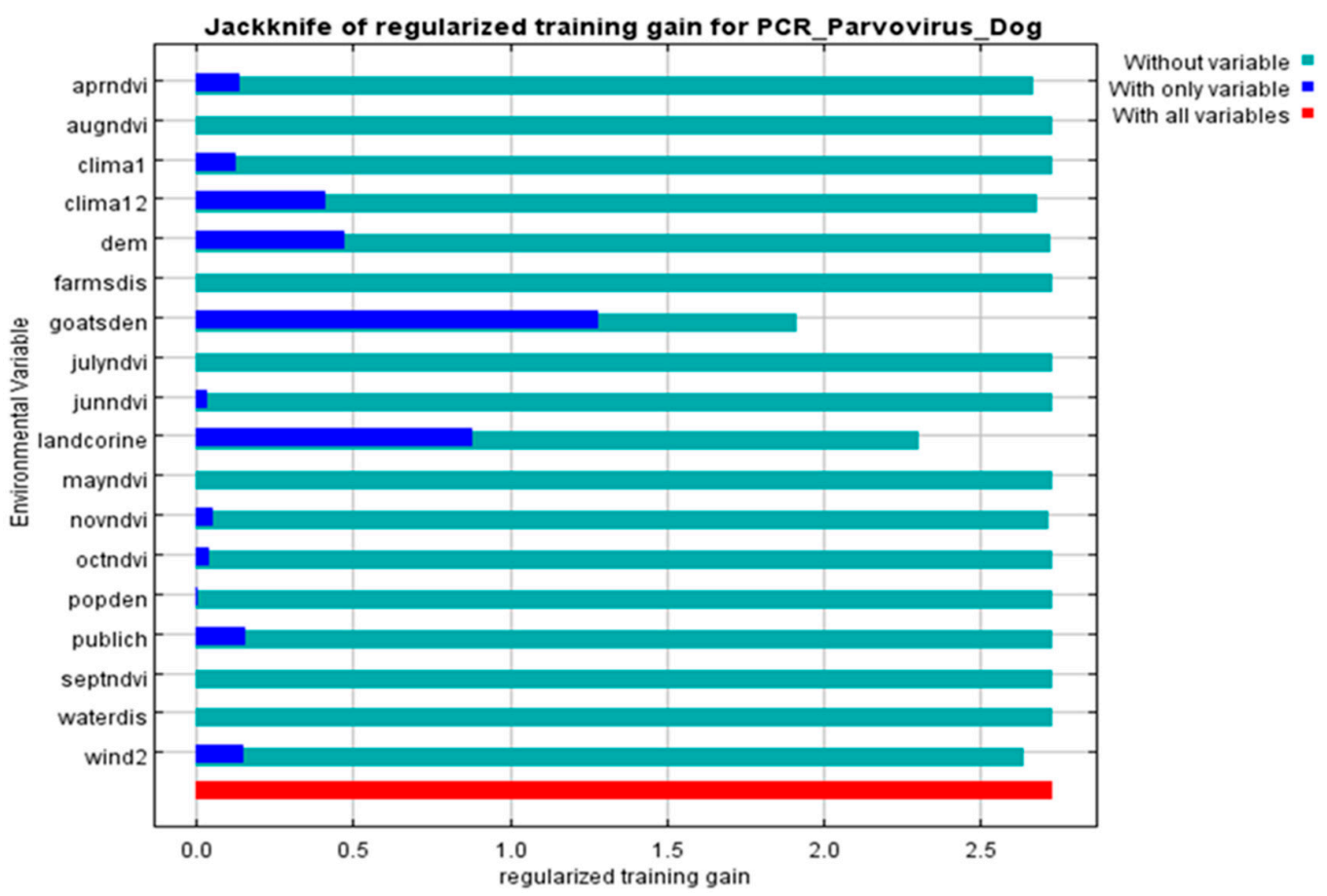

Figure 3. Jackknife of the regularized training gain (Maxent model) for CPV-2 DNA positive dogs. Livestock density (goatsden) and land uses (landcorine) were the environmental variables with substantial contribution to the model: without variable (light blue), with only one variable (blue), with all variables (red).

The environmental variables of: (i) livestock density (goatsden), (ii) land uses (landcorin), especially the categories of discontinuous urban fabric and of agroforestry formations and (iii) human population density (popden), gave a substantial contribution to the model. Specifically, livestock density referred to the density of sheep, goat and cattle per km $\mathrm{km}^{-2}$ and was the environmental variable with the highest gain, when it was used alone, while it decreased the gain the most, and when it was omitted. Therefore, it 
appeared to be the most informative variable. As for the discontinuous urban fabric class that was recognized as an additional significant environmental parameter, most of the land is covered by structures, namely buildings, roads and artificially surfaced areas, associated with the presence of vegetated areas and bare surfaces, which occupy significant surfaces in a discontinuous spatial pattern. Furthermore, the agroforestry formations class which includes land principally covered by agriculture, with significant areas of natural vegetation, was identified as an important variable. Following MaxEnt analysis that indicated the predicted probability that conditions for the presence of CPV-2 in dogs were suitable, a potential distribution of virus in dogs in Thessaly, Central Greece was depicted in Figure 4.

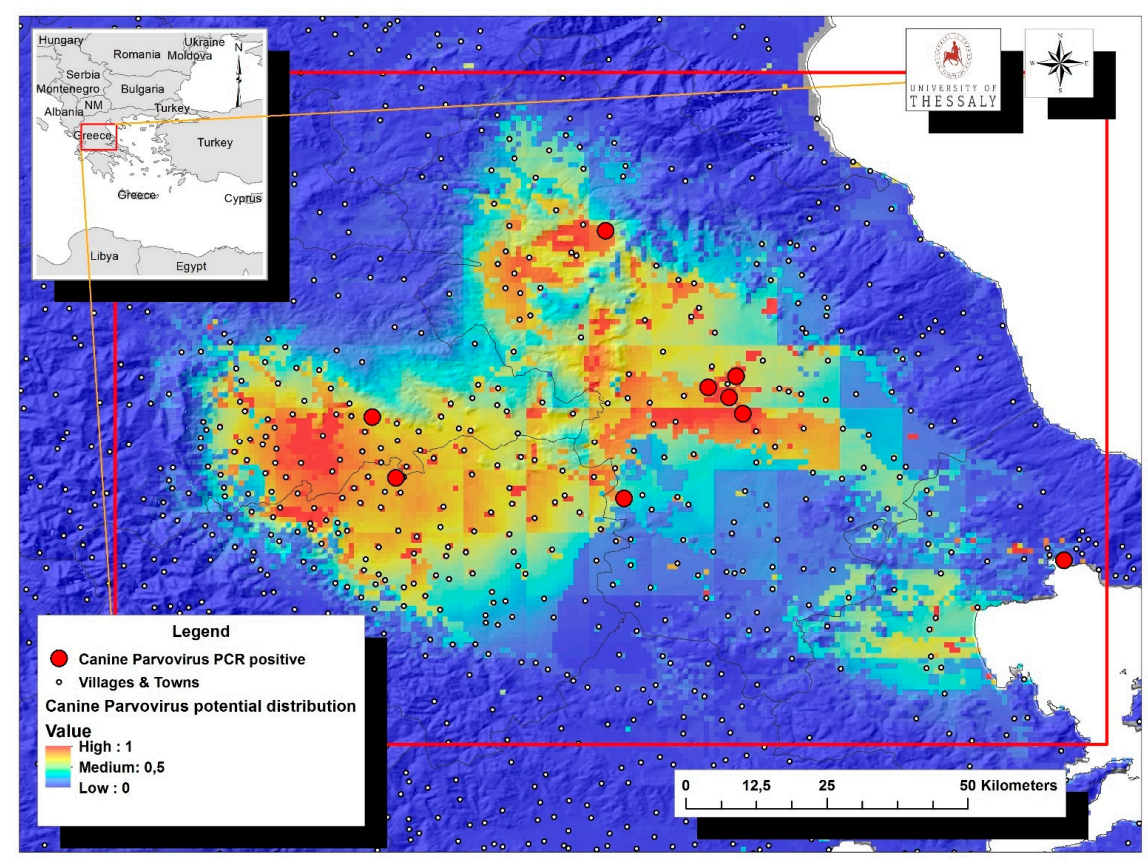

GIS:Wildlife Ecology, Zoonoses \& GIS Research Team Laboratory of Microbiology and Parasitology, Veterinary Faculty University of Thessaly Greece

Figure 4. Map of Thessaly Region displaying the potential geographic distribution of CPV-2 as predicted by MaxEnt analysis based on the confirmed virus cases in dogs (red dots). Suggested high-risk areas for CPV-2 further dispersion were indicated with brown color.

\section{Discussion}

The present study included 116 diarrheic dogs originating from four Regional Units of Thessaly in Central Greece, while 68 of them were found to be positive for the presence of CPV-2 DNA in their feces. Age and utility were identified as significant risk factors associated with parvoviral enteritis, whereas livestock density, land uses and human population density were described as important environmental variables related to virus infection. Favorable areas for the potential occurrence of CPV-2 infection in the region of Thessaly were also recognized. To our knowledge this is the first description of spatial analysis combined with molecular diagnosis of canine parvoviral enteritis in Greece.

Sixty-eight diarrheic dogs were considered as confirmed parvoviral enteritis cases since CPV-2 DNA was detected in their feces. The findings of the present study refer to occurrence of parvoviral disease rather than to exposure or infection by the pathogen. The compatible clinical picture and history supported potential diagnosis of parvoviral enteritis, which was confirmed by PCR. PCR is considered to be a golden standard diagnostic method [5] characterized by high specificity, although false negative results have been reported [28]. Hemorrhagic diarrhea was observed in 50 dogs, whereas at least one more compatible clinical symptom such as anorexia, fever, hypothermia and vomiting, was recorded in 63 animals. In respect of statistical analysis, the reported clinical signs as well as the findings of abdominal assessment were not associated with the virus presence in feces. 
Statistical analysis also revealed that gender and living environment were not related to the presence of CPV-2 DNA in feces, as reported in previous studies [18,21]. Contacts with other dogs as well as different animal species including cats, were not associated with virus detection. Overpopulation of dogs in animal shelters has been recognized as a predisposition factor for the presence of diarrhea, not specifically caused by CPV-2 [29]. In the present study, overcrowded conditions were not reported in the cases of cohabitation with other dogs. Furthermore, dogs' contacts with feces of cats, pigs, cattle, sheep and horses have not been related with virus occurrence [30], confirming our results for dogs living in close contact with different animal species.

Virus DNA was less likely to be detected in senior diarrheic dogs than in young ones. Several former reports have supported that dogs under the age of six months were more susceptible to develop parvoviral enteritis $[3,8,9,11,15,16]$, although this finding was contradicted by others [31]. In view of the long-term virus persistence in the environment and its rapid intra-species transmission, the observed disease resistance in older dogs could be attributed either to their higher levels of protective immunity due to vaccination [32], a parameter that could not be evaluated in the present study, or to a lesser extent, to their infection and subsequent survival at a younger age. Nevertheless, the common empirical belief among veterinarians remains that dogs over six weeks and under six months of age are more prone to be affected by the disease [3].

A significant association of dogs' utility and CPV-2 shedding was also detected, as the virus was more likely to be present in the feces of working dogs (hounds and shepherds) than in pet and stray ones. A previous study has identified hunting or herding activities as risk factors for CPV-2 positive results [25]. Incomplete or no vaccination has been observed more frequently in hunting and shepherd dogs, probably due to the low socio-economic background of their owners [16,23]. These dogs usually live in suburban or rural areas and tend to roam, interacting directly or indirectly with other dogs and/or wildlife species [33], which could act as potential virus sources. Furthermore, the odds of virus detection did not differ between stray and pet dogs. One could expect a higher occurrence of virus in stray dogs, as they are more often unvaccinated and live in poor conditions. Considering that they do not usually get the proper medical attention in case of illness, CPV-2 infections remain, presumably, underdiagnosed or undiagnosed, leading to severe clinical symptoms, even death. On the contrary, more pets receive treatment when and if needed, since the majority of their owners have a strong sense of responsibility to protect their health.

Spatial analysis demonstrated that livestock density was an important environmental parameter with a significant impact on the presence of canine parvoviral enteritis. Reviewing previous literature, similar results have been described by other researchers $[16,34,35]$. The Region of Thessaly consists of urban centers such as Larissa or Volos, as well as rural areas of crops, fields and livestock farms. Recently, the increased number of large carnivores in Greece, as in the rest of the European continent [36], led livestock breeders to keep a large number of shepherd dogs in order to minimize the damages caused by wildlife species. It has also been supported that livestock breeders tend to neglect vaccination, deworming treatment or regular visits to veterinarians probably due to the increased costs or to indifference [37]. Given that CPV-2 is a highly contagious virus that persists for a long period of time in the environment, cohabitation of unvaccinated or incompletely vaccinated dogs could lead to their infection, further contributing to the virus maintenance cycle.

Land uses, specifically discontinuous urban fabric and agroforestry, were related to the occurrence of CPV-2 infection. The former category comprises residential areas around the edge of urban district centers, and certain urban districts in rural areas, while the latter includes rural areas. A possible interpretation of virus association with suburban areas could be provided as their residents tend to be owners of guard, hunting or shepherd dogs, if they keep a few farmed animals for private use. The results of our statistical analysis further supported the aforementioned finding, since virus was more likely to be detected in hounds and shepherd dogs. A greater risk for CPV-2 infection was also reported for dogs that lived in rural areas, verifying previously published data [16,22]. Large numbers 
of CPV cases have been reported in rural and remote areas of Australia by using geospatial analysis [26]. In Greece, residents of rural areas are mainly farmers or livestock breeders who keep sheepdogs and have been facing financial difficulties in recent years due to economic crisis. It has been described formerly that they tend to have shorter lifespans, more difficulties making ends meet and limited access to medical facilities and education opportunities [38]. These social and economic challenges could have a negative impact on the veterinary care, diet and housing of dogs [22]. Moreover, the increased presence of unvaccinated stray or freely-roaming dogs in suburban and rural areas could contribute, in the case of their infection, to virus dissemination through interaction with healthy animals.

CPV-2 infection was also associated with human population density, as described previously by Acosta-Jamett et al. [39] who reported that dogs residing in urban areas were more likely to act as reservoirs for pathogenic infections. We believe that our finding was reasonable, since high population density usually implies an increased number of dogs, especially pets [40]. Human presence and activities could result in increased interactions between dogs, facilitating virus circulation and leading to higher infection rates [25]. Furthermore, the existence of unvaccinated stray dogs which are potential carriers of CPV-2, and live in packs and feed on uncollected garbage, leftovers or dog food [41] could contribute to virus transmission and dispersion.

This study was the first effort to simultaneously investigate possible associations of CPV-2 shedding and environmental parameters in diarrheic dogs in Greek territory. We believe that our results, as well as the map with the potential virus distribution in Thessaly Region could be used to improve the health management of both domestic and stray dogs. Interventions and educational campaigns managed by veterinarians and other stakeholders should be addressed to residents of the identified high-risk areas to promote vaccination. Considering that monitoring and understanding of CPV-2 ecology is an important tool for the determination of control and prevention measures, the results of the spatial analysis could be beneficial for dogs living in other areas with similar environmental conditions.

\section{Materials and Methods}

\subsection{Study Area}

The Region of Thessaly is divided into five Regional Units: Karditsa, Larissa, Magnesia, Sporades and Trikala, in which 25 municipalities belong, being further subdivided in 545 municipality districts. Thessaly is located in the central part of Greece and has a total area of $14,036 \mathrm{~km}^{2}$, which roughly represents $11 \%$ of the whole country. Thirty-six per cent of the land is flat and $17 \%$ is semi-mountainous, whereas the remaining $45 \%$ is mountainous [42].

\subsection{Study Design}

A total of 116 dogs presenting diarrhea were admitted to different veterinary clinics in four Regional Units of Thessaly (Karditsa, Larisa, Magnesia and Trikala) for clinical evaluation and treatment. Following clinical examination including detailed history, capture data forms were filled in as part of veterinary medical records held by each attending veterinarian, after receiving an informed consent from owner/routine care provider. Data included signalment (gender, age, breed and weight), factors related to animal management (dog utility, living environment, contact with animals and diet) and past medical history (vaccinations, deworming, recent disease). Recordings on diet and past medical history were not available in the cases of strayed dogs, thusly not evaluated in further analysis.

To assess the presence of possible CPV-2 infection, fecal samples were collected from each dog using a sterile cotton tipped swab suitable for virus collection and transportation (Sigma-VCM). Samples were sent frozen within $24 \mathrm{~h}$ for laboratory examination by PCR (Laboratory of Microbiology and Parasitology University of Thessaly, Karditsa, Greece). 


\subsection{Viral DNA Extraction}

To extract viral DNA, fecal swabs were immersed in phosphate buffered saline (PBS) and centrifuged at high speed. A proportion of $200 \mu \mathrm{L}$ from the supernatant of each sample was collected, incubated at $65^{\circ} \mathrm{C}$ for $10 \mathrm{~min}$ to inactivate PCR inhibitors and then chilled on ice [43]. A commercial DNA purification kit (Thermo Scientific Genomic DNA Purification Kit, Waltham, MA, USA) was used to complete the extraction procedure according to the manufacturer's protocol.

\subsection{Molecular Detection of $C P V-2$}

Conventional PCRs were performed using the primer pair Hfor/Hrev (Hfor: 5'CAGGTGATGAATTGCTACA-3', Hrev: $5^{\prime}$-CATTTGGATAAACTGGTGGT-3') that amplifies a $630 \mathrm{bp}$ fragment of the capsid protein-encoding VP2 gene according to Decaro et al. [44]. Each reaction mixture was adjusted in a final volume of $50 \mu \mathrm{L}$ and contained $1 \times$ PCR buffer, $2 \mathrm{mM} \mathrm{MgCl} 2,2.5 \mathrm{mM}$ of each deoxynucleotide, $0.5 \mu \mathrm{M}$ of each primer, $2 \mathrm{U}$ Taq DNA Polymerase (Thermo Scientific Maxima Hot Start Taq DNA polymerase) and $5 \mu \mathrm{L}$ of DNA extract. Cycling conditions included an initial step at $94{ }^{\circ} \mathrm{C}$ for $10 \mathrm{~min}$, followed by 40 cycles of denaturation at $94{ }^{\circ} \mathrm{C}$ for $30 \mathrm{~s}$, annealing at $50{ }^{\circ} \mathrm{C}$ for $1 \mathrm{~min}$ and extension at $72^{\circ} \mathrm{C}$ for $1 \mathrm{~min}$, and a final extension step at $72{ }^{\circ} \mathrm{C}$ for $10 \mathrm{~min}$. Eight $\mu \mathrm{L}$ of each amplified product were analyzed by electrophoresis in a $2 \%$ agarose gel and product sizes were determined using a 100 bp DNA marker.

\subsection{Statistical Analysis}

Statistical analyses were performed using Stata 13.1 (Stata Statistical Software, College Station, TX, USA) and evaluated for significance at the 5\% level. Descriptive statistics of collected data were performed. The evaluation of the association between detection (presence or absence) of CPV-2 DNA in feces with the parameters of dogs' history, collected upon submission to veterinary clinics, was performed with the use of a logistic regression model. Presence or absence of CPV-2 DNA in feces was the dependent variable, while the parameters: (i) gender: male or female, (ii) age: young ( $<1$ years old), adult $(\geq 1$ and $<9$ years old) or senior ( $\geq 9$ years old), (iii) utility: companion, working or stray dog, (iv) living environment: indoors, outdoors or both, (v) contact with dogs, cats or other animal species, (vi) abdominal palpation: normal or abnormal findings, (vii) anorexia: presence or absence, (viii) hemorrhagic diarrhea: presence or absence, (ix) temperature: within reference interval, fever or hypothermia and $(\mathrm{x})$ vomiting: presence or absence, were the independent covariates. All independent variables were initially screened one by one in univariate logistic regression models. During this process, a significance level of 0.25 was used as the screening criterion, since a more traditional level (such as $p<0.05$ ) often fails to identify variables known to be important [45]. Then, variables with $p<0.25$ were offered simultaneously to a full model, subsequently reduced by backwards elimination [46] until only significant $(p<0.05)$ variables remained. Two-factor interactions were created between the remaining variables and offered one at a time to the model. Finally, we offered previously deleted variables one-by-one to the final model, in order to ensure that no variable which significantly added to the model was omitted. The goodness of fit of the employed model was evaluated with the lfit post-estimation command.

\subsection{Environmental Variables}

Environmental variables were divided into three major classes: climatic conditions, topography and human activities. Climate indices were derived from the WorldClim version 1.4. [47], while digital elevation model (altitude) was extracted from CGIAR-CSI GeoPortal (http: //srtm.csi.cgiar.org/Index.asp, accessed on 25 March 2021). Hydrological data were extracted from HydroSHEDS (https: / /hydrosheds.cr.usgs.gov/, accessed on 25 March 2021) and wind speed was downloaded and formatted from the Hellenic Regulatory Authority for Energy (http:/ /www.rae.gr, accessed on 25 March 2021). Human development (municipalities/district/community) were downloaded from the Greek National Spatial Data Infrastructure (http://www.geodata.gov.gr, accessed on 25 March 2021). Land uses and human population density were derived from European Environment Agency (Copenhagen, 
Denmark (http:/ /www.eea.europa.eu/data-and-maps, accessed on 25 March 2021)). The normalized difference vegetation index (NDVI) was extracted from the Copernicus European earth monitoring program (http:/ / www.copernicus.eu, accessed on 25 March 2021) (FDC, Vincennes, France). ArcGIS 10.1 software (ESRI, Redlands, CA, USA) was used to create 34 environmental layers for the analysis. Data sets were converted to a common projection map extent and resolution prior to use in the modeling program and are presented in Table 3.

Table 3. The 34 environmental variables included in GIS analysis.

\begin{tabular}{|c|c|}
\hline Code & Environmental Variable \\
\hline clima1 & Annual mean temperature $\left({ }^{\circ} \mathrm{C}\right)$ \\
\hline clima2 & Mean diurnal temperature range $\left({ }^{\circ} \mathrm{C}\right)$ \\
\hline clima3 & Isothermality $($ clima2 $/$ clima $7 \times 100)$ \\
\hline clima4 & Temperature seasonality (standard deviation $\times 100$ ) \\
\hline clima5 & Maximum temperature of warmest month $\left({ }^{\circ} \mathrm{C}\right)$ \\
\hline clima6 & Minimum temperature of coldest month $\left({ }^{\circ} \mathrm{C}\right)$ \\
\hline clima7 & Temperature annual range $\left({ }^{\circ} \mathrm{C}\right)$ \\
\hline clima8 & Mean temperature of wettest quarter $\left({ }^{\circ} \mathrm{C}\right)$ \\
\hline clima9 & Mean temperature of driest quarter $\left({ }^{\circ} \mathrm{C}\right)$ \\
\hline clima10 & Mean temperature of warmest quarter $\left({ }^{\circ} \mathrm{C}\right)$ \\
\hline clima11 & Mean temperature of coldest quarter $\left({ }^{\circ} \mathrm{C}\right)$ \\
\hline clima12 & Total annual precipitation (mm) \\
\hline clima13 & Total precipitation of wettest month (mm) \\
\hline clima14 & Total precipitation of driest month (mm) \\
\hline clima15 & Precipitation seasonality (coefficient of variation) \\
\hline clima16 & Total precipitation of wettest quarter (mm) \\
\hline clima17 & Total precipitation of driest quarter $(\mathrm{mm})$ \\
\hline clima18 & Total precipitation of warmest quarter (mm) \\
\hline clima19 & Total precipitation of coldest quarter (mm) \\
\hline wind 2 & Annual mean wind speed $\left(\mathrm{m} \mathrm{s}^{-1}\right)$ \\
\hline dem & Altitude (m) \\
\hline waterdis & Distance from water collections (m) \\
\hline farmsdis & Distance from small ruminant farms (m) \\
\hline goatsden & Sheep, goat and cattle density (animals $\mathrm{km}^{-2}$ ) \\
\hline landcorine & Land use (principal) \\
\hline aprndvi & $\begin{array}{c}\text { April } \\
\text { NDVI }^{1}\end{array}$ \\
\hline mayndvi & May NDVI \\
\hline junendvi & June NDVI \\
\hline julyndvi & July NDVI \\
\hline augndvi & August NDVI \\
\hline sepndvi & September NDVI \\
\hline octndvi & October NDVI \\
\hline novndvi & November NDVI \\
\hline popden & Human population density (people $\mathrm{km}^{-2}$ ) \\
\hline
\end{tabular}

${ }^{1}$ NDVI: normalized difference vegetation index. 


\subsection{Ecological Niche Modeling (ENM)}

Maximum entropy modeling (MaxEnt software ver. 3.3.3) [27] was used to predict the appropriate ecological niches of positive CPV-2 DNA dogs. MaxEnt method requires presence-only data, utilizes both continuous and categorical data and includes efficient deterministic algorithms and mathematical definitions [27]. CPV-2 positive dogs were used as occurrence points for the ENM procedure. The goodness of fit of the model predictions was evaluated by the mean area under the curve (AUC) of the receiver operating characteristic (ROC) curve by giving an estimation between 0 and 1 for the probability of virus presence. Jackknife test option was used to eliminate the number of environmental variables to those that exhibited a substantial influence on the model.

Author Contributions: Conceptualization, M.K., L.V.A., A.G., V.S. (Vassiliki Spyrou) and C.B.; methodology, M.K., L.V.A., A.G., V.S. (Vassilis Skampardonis), V.S. (Vassiliki Spyrou) and C.B.; software, A.G. and V.S. (Vassilis Skampardonis); validation, M.K., L.V.A., A.G., V.S. (Vassilis Skampardonis), M.S., G.V., Z.A., A.T., D.C.C., V.S. (Vassiliki Spyrou) and C.B.; formal analysis, M.K., A.G. and V.S. (Vassilis Skampardonis); investigation, M.K., A.G., V.S. (Vassilis Skampardonis), M.S., G.V., Z.A., A.T. and D.C.C.; data curation, M.K., L.V.A., A.G., V.S. (Vassilis Skampardonis) and M.S.; writing—original draft preparation, M.K., L.V.A., A.G., V.S. (Vassilis Skampardonis) and M.S.; writing—review and editing, M.K., L.V.A., A.G., V.S. (Vassilis Skampardonis), M.S., V.S. (Vassiliki Spyrou) and C.B.; visualization, A.G. and V.S. (Vassilis Skampardonis); supervision, L.V.A., V.S. (Vassiliki Spyrou) and C.B.; project administration, L.V.A., V.S. (Vassiliki Spyrou) and C.B.; funding acquisition, L.V.A., V.S. (Vassiliki Spyrou) and C.B. All authors have read and agreed to the published version of the manuscript.

Funding: This research was co-funded by the European Union (European Social Fund-ESF) and national funds through the Operational Program "Education and Lifelong Learning" of the National Strategic Reference Framework (NSRF)—Research Funded Project: THALES. Investing in knowledge society through the European Social Fund (grant number: MIS 377266).

Institutional Review Board Statement: Ethical review and approval were waived for this study since sampling was performed only once for diagnostic evaluation and no research on animals, as defined in the EU Ethics for Researchers document (European Commission, 2013, Ethics for ResearchersFacilitating Research Excellence in FP7, Luxembourg: Office for Official Publications of the European Communities, ISBN 978-92-79-28854-8), was conducted. Informed consent was provided by animal owners or care providers regarding using results and animal data for research purposes.

Informed Consent Statement: Not applicable.

Data Availability Statement: Most data are presented in this study. The remaining data are available on request from the corresponding author.

Acknowledgments: We gratefully acknowledge all the veterinarians that assisted with the collection of the samples for this study.

Conflicts of Interest: The authors declare no conflict of interest. The funders had no role in the design, execution, interpretation, or writing of the study.

\section{References}

1. Decaro, N.; Desario, C.; Billi, M.; Mari, V.; Elia, G.; Cavalli, A.; Martella, V.; Buonavoglia, C. Western European Epidemiological Survey for Parvovirus and Coronavirus Infections in Dogs. Vet. J. 2011, 187, 195-199. [CrossRef]

2. Decaro, N.; Buonavoglia, C. Canine Parvovirus-A Review of Epidemiological and Diagnostic Aspects, with Emphasis on Type 2c. Vet. Microbiol. 2012, 155, 1-12. [CrossRef]

3. Goddard, A.; Leisewitz, A.L. Canine Parvovirus. Vet. Clin. N. Am. Small Anim. Pract. 2010, 40, 1041-1053. [CrossRef] [PubMed]

4. Decaro, N.; Cirone, F.; Desario, C.; Elia, G.; Lorusso, E.; Colaianni, M.L.; Martella, V.; Buonavoglia, C. Severe Parvovirus in a 12-Year-Old Dog That Had Been Repeatedly Vaccinated. Vet. Rec. 2009, 164, 593-595. [CrossRef] [PubMed]

5. Mylonakis, M.E.; Kalli, I.; Rallis, T.S. Canine Parvoviral Enteritis: An Update on the Clinical Diagnosis, Treatment, and Prevention. Vet. Med. 2016, 7, 91-100. [CrossRef] [PubMed]

6. Duque-García, Y.; Echeverri-Zuluaga, M.; Trejos-Suarez, J.; Ruiz-Saenz, J. Prevalence and Molecular Epidemiology of Canine Parvovirus 2 in Diarrheic Dogs in Colombia, South America: A Possible New CPV-2a Is Emerging? Vet. Microbiol. 2017, 201, 56-61. [CrossRef] [PubMed] 
7. Apaa, T.T.; Daly, J.M.; Tarlinton, R.E. Canine Parvovirus (CPV-2) Variants Circulating in Nigerian Dogs. Vet. Rec. Open $2016,3$. [CrossRef] [PubMed]

8. Zhao, Z.; Liu, H.; Ding, K.; Peng, C.; Xue, Q.; Yu, Z.; Xue, Y. Occurrence of Canine Parvovirus in Dogs from Henan Province of China in 2009-2014. BMC Vet. Res. 2016, 12. [CrossRef]

9. Duijvestijn, M.; Mughini-Gras, L.; Schuurman, N.; Schijf, W.; Wagenaar, J.A.; Egberink, H. Enteropathogen Infections in Canine Puppies: (Co-)Occurrence, Clinical Relevance and Risk Factors. Vet. Microbiol. 2016, 195, 115-122. [CrossRef]

10. Filipov, C.; Desario, C.; Patouchas, O.; Eftimov, P.; Gruichev, G.; Manov, V.; Filipov, G.; Buonavoglia, C.; Decaro, N. A Ten-Year Molecular Survey on Parvoviruses Infecting Carnivores in Bulgaria. Transbound. Emerg. Dis. 2016, 63, 460-464. [CrossRef] [PubMed]

11. Cavalli, A.; Desario, C.; Kusi, I.; Mari, V.; Lorusso, E.; Cirone, F.; Kumbe, I.; Colaianni, M.L.; Buonavoglia, D.; Decaro, N. Detection and Genetic Characterization of Canine Parvovirus and Canine Coronavirus Strains Circulating in District of Tirana in Albania. J. Vet. Diagn. Invest. 2014, 26, 563-566. [CrossRef] [PubMed]

12. Behdenna, A.; Lembo, T.; Calatayud, O.; Cleaveland, S.; Halliday, J.E.B.; Packer, C.; Lankester, F.; Hampson, K.; Craft, M.E.; Czupryna, A.; et al. Transmission Ecology of Canine Parvovirus in a Multi-Host, Multi-Pathogen System. Proc. R. Soc. Lond. 2019, 286, 20182772. [CrossRef]

13. Decaro, N.; Desario, C.; Campolo, M.; Elia, G.; Martella, V.; Ricci, D.; Lorusso, E.; Buonavoglia, C. Clinical and Virological Findings in Pups Naturally Infected by Canine Parvovirus Type 2 Glu-426 Mutant. J. VET Diagn. Invest. 2005, 17, 133-138. [CrossRef]

14. Sykes, J.E. Canine Parvovirus Infections and Other Viral Enteritides. Canine Feline Infect. Dis. 2014, 141-151. [CrossRef]

15. Ling, M.; Norris, J.M.; Kelman, M.; Ward, M.P. Risk Factors for Death from Canine Parvoviral-Related Disease in Australia. Vet Microbiology 2012, 158, 280-290. [CrossRef] [PubMed]

16. Zourkas, E.; Ward, M.P.; Kelman, M. Canine Parvovirus in Australia: A Comparative Study of Reported Rural and Urban Cases. Vet. Microbiol. 2015, 181, 198-203. [CrossRef]

17. Iris Kalli, S.; Leontides, L.E.; Mylonakis, M.; Adamama-Moraitou, K.; Rallis, T.F.; Koutinas, A. Factors Affecting the Occurrence, Duration of Hospitalization and Final Outcome in Canine Parvovirus Infection. Res. Vet. Sci. 2010, 89, 174-178. [CrossRef] [PubMed]

18. Godsall, S.A.; Clegg, S.R.; Stavisky, J.H.; Radford, A.D.; Pinchbeck, G. Epidemiology of Canine Parvovirus and Coronavirus in Dogs Presented with Severe Diarrhoea to PDSA PetAid Hospitals. Vet. Rec. 2010, 167, 196-201. [CrossRef]

19. de Almeida Curi, N.H.; Massara, R.L.; de Oliveira Paschoal, A.M.; Soriano-Araújo, A.; Lobato, Z.I.P.; Demétrio, G.R.; Chiarello, A.G.; Passamani, M. Prevalence and Risk Factors for Viral Exposure in Rural Dogs around Protected Areas of the Atlantic Forest. BMC Vet. Res 2016, 12. [CrossRef]

20. Prittie, J. Canine Parvoviral Enteritis: A Review of Diagnosis, Management, and Prevention. J. Vet. Emerg. Crit. Care 2004, 14, 167-176. [CrossRef]

21. Miranda, C.; Carvalheira, J.; Parrish, C.R.; Thompson, G. Factors Affecting the Occurrence of Canine Parvovirus in Dogs. Vet. Microbiol. 2015, 180, 59-64. [CrossRef]

22. Brady, S.; Norris, J.M.; Kelman, M.; Ward, M.P. Canine Parvovirus in Australia: The Role of Socio-Economic Factors in Disease Clusters. Vet. J. 2012, 193, 522-528. [CrossRef] [PubMed]

23. Kelman, M.; Barrs, V.R.; Norris, J.M.; Ward, M.P. Socioeconomic, Geographic and Climatic Risk Factors for Canine Parvovirus Infection and Euthanasia in Australia. Prev. Vet. Med. 2020, 174, 104816. [CrossRef] [PubMed]

24. Rika-Heke, T.; Kelman, M.; Ward, M.P. The Relationship between the Southern Oscillation Index, Rainfall and the Occurrence of Canine Tick Paralysis, Feline Tick Paralysis and Canine Parvovirus in Australia. Vet. J. 2015, 205, 87-92. [CrossRef]

25. Acosta-Jamett, G.; Surot, D.; Cortés, M.; Marambio, V.; Valenzuela, C.; Vallverdu, A.; Ward, M.P. Epidemiology of Canine Distemper and Canine Parvovirus in Domestic Dogs in Urban and Rural Areas of the Araucanía Region in Chile. Vet. Microbiol. 2015, 178, 260-264. [CrossRef]

26. Kelman, M.; Ward, M.P.; Barrs, V.R.; Norris, J.M. The Geographic Distribution and Financial Impact of Canine Parvovirus in Australia. Transbound. Emerg. Dis. 2019, 66, 299-311. [CrossRef] [PubMed]

27. Phillips, S.J.; Anderson, R.P.; Schapire, R.E. Maximum Entropy Modeling of Species Geographic Distributions. Ecol. Model. 2006, 190, 231-259. [CrossRef]

28. Faz, M.; Martinez, J.S.; Quijano-Hernandez, I.; Fajardo, R. Reliability of Clinical Diagnosis and Laboratory Testing Techniques Currently Used for Identification of Canine Parvovirus Enteritis in Clinical Settings. J. Vet. Med. Sci. 2017, 79, 213-217. [CrossRef]

29. Sokolow, S.H.; Rand, C.; Marks, S.L.; Drazenovich, N.L.; Kather, E.J.; Foley, J.E. Epidemiologic Evaluation of Diarrhea in Dogs in an Animal Shelter. Am. J. Vet. Res. 2005, 66, 1018-1024. [CrossRef]

30. Stavisky, J.; Radford, A.D.; Gaskell, R.; Dawson, S.; German, A.; Parsons, B.; Clegg, S.; Newman, J.; Pinchbeck, G. A Case-Control Study of Pathogen and Lifestyle Risk Factors for Diarrhoea in Dogs. Prev. Vet. Med. 2011, 99, 185-192. [CrossRef] [PubMed]

31. Ward, M.P.; Kelman, M. Companion Animal Disease Surveillance: A New Solution to an Old Problem? Spat. Spatiotemporal Epidemiol. 2011, 2, 147-157. [CrossRef]

32. Houston, D.M.; Ribble, C.S.; Head, L.L. Risk Factors Associated with Parvovirus Enteritis in Dogs: 283 Cases (1982-1991). J. Am. Vet. Med. Assoc. 1996, 208, 542-546. [PubMed] 
33. Vieira, F.V.; Hoffmann, D.J.; Fabri, C.U.F.; Bresciani, K.D.S.; Gameiro, R.; Flores, E.F.; Cardoso, T.C. Circulation of Canine Parvovirus among Dogs Living in Human-Wildlife Interface in the Atlantic Forest Biome, Brazil. Heliyon 2018, 3. [CrossRef] [PubMed]

34. Belsare, A.V.; Gompper, M.E. Assessing Demographic and Epidemiologic Parameters of Rural Dog Populations in India during Mass Vaccination Campaigns. Prev. Vet. Med. 2013, 111, 139-146. [CrossRef] [PubMed]

35. Orozco, M.M.; Miccio, L.; Enriquez, G.F.; Iribarren, F.E.; Gürtler, R.E. Serologic Evidence of Canine Parvovirus in Domestic Dogs, Wild Carnivores, and Marsupials in the Argentinean Chaco. J. Zoo Wildl. Med. 2014, 45, 555-563. [CrossRef]

36. Chapron, G.; Kaczensky, P.; Linnell, J.D.C.; von Arx, M.; Huber, D.; Andrén, H.; López-Bao, J.V.; Adamec, M.; Álvares, F.; Anders, O.; et al. Recovery of Large Carnivores in Europe's Modern Human-Dominated Landscapes. Science 2014, 346, 1517-1519. [CrossRef]

37. Millán, J.; Candela, M.G.; Palomares, F.; Cubero, M.J.; Rodríguez, A.; Barral, M.; de la Fuente, J.; Almería, S.; León-Vizcaíno, L. Disease Threats to the Endangered Iberian Lynx (Lynx Pardinus). Vet. J. 2009, 182, 114-124. [CrossRef] [PubMed]

38. Eurofound. Eurofound Yearbook 2014: Living and Working in Europe; Publications Office of the European Union: Luxembourg, 2015.

39. Acosta-Jamett, G.; Cleaveland, S.; Cunningham, A.A.; Bronsvoort, B.D. Demography of Domestic Dogs in Rural and Urban Areas of the Coquimbo Region of Chile and Implications for Disease Transmission. Prev. Vet. Med. 2010, 94, 272-281. [CrossRef] [PubMed]

40. Australian Companion Animal Council. Contribution of the Pet Care Industry to the Australian Economy, 7th ed.; Animal Health Alliance: Las Vegas, NV, USA, 2010.

41. Guilloux, A.G.A.; Panachão, L.I.; Alves, A.J.S.; Zetun, C.B.; Cassenote, A.J.F.; Dias, R.A.; Guilloux, A.G.A.; Panachão, L.I.; Alves, A.J.S.; Zetun, C.B.; et al. Stray Dogs in Urban Fragments: Relation between Population's Perception of Their Presence and Socio-Demographic Factors. Pesq. Vet. Bras. 2018, 38, 89-93. [CrossRef]

42. Domenikiotis, C.; Spiliotopoulos, M.; Tsiros, E.; Dalezios, N.R. Remotely Sensed Estimation of Annual Cotton Production under Different Environmental Conditions in Central Greece. Phys. Chem. Earth Parts A/B/C 2005, 30, 45-52. [CrossRef]

43. Uwatoko, K.; Sunairi, M.; Nakajima, M.; Yamaura, K. Rapid Method Utilizing the Polymerase Chain Reaction for Detection of Canine Parvovirus in Feces of Diarrheic Dogs. Vet. Microbiol. 1995, 43, 315-323. [CrossRef]

44. Decaro, N.; Elia, G.; Martella, V.; Desario, C.; Campolo, M.; Trani, L.D.; Tarsitano, E.; Tempesta, M.; Buonavoglia, C. A Real-Time PCR Assay for Rapid Detection and Quantitation of Canine Parvovirus Type 2 in the Feces of Dogs. Vet. Microbiol. 2005, 105, 19-28. [CrossRef] [PubMed]

45. Mickey, R.M.; Greenland, S. The Impact of Confounder Selection Criteria on Effect Estimation. Am. J. Epidemiol. 1989, 129, 125-137. [CrossRef] [PubMed]

46. Hosmer, D.W.; Lemeshow, S. Applied Logistic Regression; Wiley: New York, NY, USA, 1989; ISBN 978-0-471-61553-8.

47. Hijmans, R.J.; Cameron, S.E.; Parra, J.L.; Jones, P.G.; Jarvis, A. Very High Resolution Interpolated Climate Surfaces for Global Land Areas. Int. J. Climatol. 2005, 25, 1965-1978. [CrossRef] 